\title{
Variasi Gen matK dan Filogenetik Tumbuhan Kantong Semar (Nepenthes sp.) dari Gunung Mahawu dan Gunung Soputan di Sulawesi Utara (The Variation of matK Gene and the Phylogeny of Nepenthes sp. Obtained from Mount Mahawu and Mount Soputan in North Sulawesi)
}

\author{
Jennifer S. Tambuwun ${ }^{1)}$, Beivy J. Kolondam ${ }^{1)}$, Trina E. Tallei1)* \\ 1)Program Studi Biologi, Jurusan Biologi FMIPA UNSRAT Manado, 95115 \\ “Email korespondensi: trina_tallei@unsrat.ac.id
}

Diterima 7 Januari 2017, diterima untuk dipublikasikan 7 Februari 2017

\begin{abstract}
Abstrak
Kantong semar (Nepenthes sp.) merupakan salah satu tumbuhan langka yang dilindungi. Eksploitasi yang berlebihan, serta alih fungsi hutan menjadi ancaman bagi kehidupan Nepenthes sp. Penelitian ini bertujuan untuk menentukan variasi gen matK dari tumbuhan Nepenthes sp. di Gunung Mahawu (JTM) dan Gunung Soputan (JTS) di Sulawesi Utara dan membandingkannya dengan kerabat terdekat di GenBank, serta membuat pohon filogenetiknya. Hasil penelitian menunjukkan bahwa hanya terdapat satu perbedaan nukleotida sekuens gen matK antara Nepenthes sp. dari Gunung Mahawu dan Gunung Soputan. Selain itu, variasi juga ditunjukan pada Nepenthes sp. yang diperoleh dari basis data GenBank dengan adanya perbedaan 1-7 basa nukleotida dengan sampel penelitian ini. Hasil analisis menggunakan ABGD (Automatic Barcode Gap Discovery) menunjukkan bahwa variasi intraspesies untuk Nepenthes sp. berada dalam rentang 0,000-0,004. Apabila mempertimbangkan barcode gap tersebut sebagai pembatas spesies, maka diasumsikan bahwa JTM, JTS, N. fusca, N. pilosa, N. maxima, N. faizaliana, dan N. clipeata merupakan spesies yang sama. $\mathrm{Hal}$ ini ditunjang oleh rekonstruksi pohon filogenetik menggunakan gen matK.

Kata Kunci: $A B G D$, barcode gap, gen matK, Nepenthes sp., pohon filogenetik, variasi sekuens.
\end{abstract}

\begin{abstract}
Tropical pitcher plant (Nepenthes sp.) is listed as one of the endangered and protected plants. Excessive exploitation and forest conversion threaten the life of this Nepenthes sp. This research was aimed to determine variation in matK gene of Nepenthes sp. obtained from Mount Mahawu (JTM) and Mount Soputan (JTS) North Sulawesi, and compare the matK sequences with their allied taxa in public domain data base. Analysis of matK gene showed that there was only one nucleotide difference of matK gene sequence between Mahawu and Soputan samples. There were 1-7 different nucleotides between those samples and their allied taxa. Analysis of barcode gap using ABGD (Automatic Barcode Gap Discovery) showed that the range of intraspecies variation of Nepenthes sp. was $0,000-0,004$. Considering this barcode gap generated from ABGD as species delimination, it could be assumed that JTM, JTS, N. fusca, N. pilosa, N. maxima, $\mathrm{N}$. faizaliana, dan N. clipeata were the same species. These results were also supported by the reconstruction of phylogenetic tree using matK gene.

Keywords: ABGD, barcode gap, matK gene, Nepenthes sp., phylogeneteic tree, sequence variation.
\end{abstract}




\section{PENDAHULUAN}

Indonesia merupakan salah satu negara yang memilki tingkat keanekaragaman plasma nutfah yang tinggi. Salah satu plasma nutfah yang banyak terdapat di Indonesia yaitu kantong semar (Nepenthes sp.) (Mansur 2008). Nepenthes sp. merupakan tumbuhan yang unik karena pada ujung daunnya terbentuk sebuah kantong yang disebut pitcher. Kantong tersebut digunakan Nepenthes sp. untuk menjebak serangga sehingga tumbuhan Nepenthes sp. dapat menyerap nutrisi dari serangga yang terjebak dalam kantongnya (Scholz et al. 2010, Mithofer 2011).

Populasi Nepenthes sp. semakin berkurang di alam disebabkan oleh alih fungsi lahan menjadi kawasan pemukiman, perkebunan, perladangan, pertanian, dan faktor kebakaran hutan serta eksploitasi tumbuhan ini untuk kepentingan ekonomi (Shingh et al. 2011, Robinson et al. 2009). Populasi Nepenthes sp. yang semakin berkurang membuat pemerintah menetapkan Nepenthes sp. sebagai salah satu tumbuhan yang harus dilindungi berdasarkan UU No. 5 Tahun 1990, Peraturan Pemerintah No. 7 Tahun 1999 dan masuk dalam kategori Red List IUCN (International Union for Conservation of Nature) sebagai tumbuhan yang rentan kepunahan (Samsurianto 2010).

Penelitian mengenai variasi genetik Nepenthes sp. di beberapa daerah di Sulawesi Utara perlu dilakukan untuk tujuan konservasi. Variasi genetik tersebut diperoleh dari sekuens DNA barcode. DNA barcoding merupakan salah satu metode yang telah banyak berkembang untuk mempelajari, mengidentifikasi serta menganalisis keragaman genetik antar spesies secara molekuler (Kress dan Erickson 2008). Dalam menggunakan teknologi DNA barcoding terdapat dua gen standar yang telah di setujui dan direkomendasikan oleh Konsorsium Barcode of Life (CBoL). Kedua gen tersebut yaitu rbcL (ribulose-1,5biphosphate carboxylase oxygenase) dan matK (maturase $\mathrm{K}$ ) (Kress et al. 2010).

Sampel Nepenthes sp. diperoleh dari Gunung Mahawu dan Gunung Soputan. Kedua lokasi ini dipilih karena masih kurangnya konservasi spesies tumbuhan ini pada lokasi tersebut (Butarbutar et al. 2014) Penelitian ini bertujuan untuk mengetahui variasi genetik tumbuhan Nepenthes sp. dari Gunung Mahawu dan Gunung Soputan dan membandingkannya dengan kerabat terdekat di GenBank serta membuat pohon filogenetik Nepenthes sp.

\section{METODE \\ Ekstraksi DNA tumbuhan Nepenthes sp.}

Ekstraksi DNA dilakukan menggunakan Axyprep Multisource Genomic DNA miniprep kit (Axygen). Modifikasi dilakukan untuk memaksimalkan lisis dengan waktu inkubasi 1 jam dalam suhu $60^{\circ} \mathrm{C}$ (Kolondam et al., 2013). Bagian sampel yang digunakan dalam ekstraksi yaitu potongan kecil daun muda tumbuhan Nepenthes sp. yang diperoleh dari Gunung Mahawu (JTM) dan Gunung Soputan (JTS).

\section{Amplifikasi Gen matK dengan Teknik PCR}

Proses amplifikasi dilakukan dengan membuat Master Mix PCR dalam $40 \mu \mathrm{L}$ reaksi PCR. Komponen yang di campur untuk satu kali reaksi yaitu $20 \mu \mathrm{L} 2 \mathrm{X}$ KapaTaq, 1,5 $\mu \mathrm{L}$ primer forward, 1,5 $\mu \mathrm{L}$ primer reverse, $15 \mu \mathrm{L}$ ddH2O dan $2 \mu \mathrm{L}$ templat DNA. Pasangan primer yang digunakan untuk amplifikasi sekuensing gen matk yaitu matk-3F-R (5'-CGT ACA GTA CTT TTG TGT TTA CGA G-3') dan matk-1R-F (5'ACC CAG TCC 
ATC TGG AAA TCT TGG TTC-3') (Kuzmina et al., 2012). Pengaturan suhu untuk proses PCR dimulai dengan kondisi denaturasi awal pada suhu $95^{\circ} \mathrm{C}$ selama 2 menit yang kemudian dilanjutkan dengan 35 siklus yang terdiri atas tahap denaturasi pada suhu $95^{\circ} \mathrm{C}$ selama 30 detik, penempelan primer pada cetakan suhu $50^{\circ} \mathrm{C}$ selama 30 detik, dan polimerisasi pada $72^{\circ} \mathrm{C}$ selama 50 detik (Tallei et al. 2016). DNA hasil PCR divisualisasi menggunakan elektroforesis gel agarosa $1 \%$ dan sisanya dikirim untuk sekuensing ke First Base Malaysia. sekuensing bersama primer. Proses sekuensing dilakukan sebanyak dua kali dengan arah yang berbeda (forward dan reverse) sesuai primer yang ada.

\section{Analisis Data}

Data hasil sekuensing disunting menggunakan Genious v5.6 mengikuti prosedur Tallei dan Kolondam (2015). Global Alignment yang terintegrasi dalam Geneious digunakan dalam proses pairwise alignment untuk memadukan hasil sekuensing yang menggunakan primer reverse (matk-1R-f) dengan primer forward (matK-3F-r). Sekuens matk digunakan untuk mencari sekuens serupa di basis data publik (GenBank). Semua sekuens matK dijajarkan menggunakan Multalin V.5.4.1

(http://multalin.toulouse.inra.fr/multali $\mathrm{n} /$ ). Penjajaran akhir dan matriks persentase identitas (percent identity matrix) dibuat menggunakan Clustal Omega

(http://www.ebi.ac.uk/Tools/msa/clus talo/). Metode UPGMA digunakan untuk membuat pohon filogenetik dan untuk perhitungan jarak genetik menggunakan metode Kimura's 2parameter yang terintegrasi di dalam piranti lunak MEGA7 (Tamura et al. 2013).

\section{HASIL DAN PEMBAHASAN}

Amplifikasi berhasil dilakukan untuk keempat sampel tumbuhan Nepenthes sp. dari Gunung Mahawu (JTM1 dan JTM2) dan dari Gunung Soputan (JTS1 dan JTS2). Pita hasil amplipikasi DNA terlihat jelas untuk keempat sampel seperti yang ditunjukan pada Gambar 1.

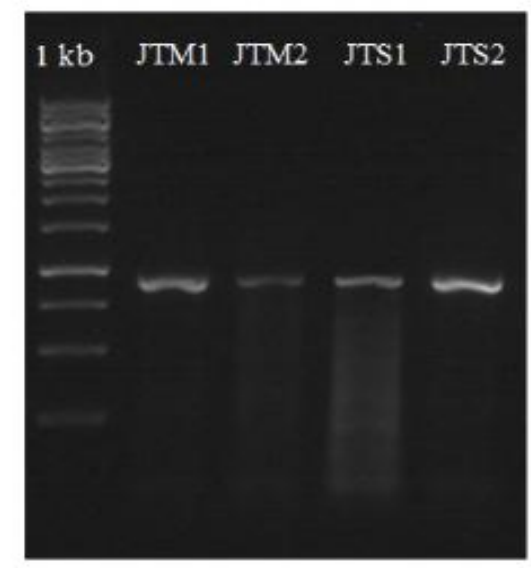

Gambar 1. Visualisasi hasil amplifikasi DNA gen matK dari sampel tumbuhan Nepenthes sp. dari Gunung Mahawu (JTM) dan Gunung Soputan (JTS)

Hasil penjajaran menunjukan kemiripan $100 \%$ antara sampel dari Gunung Mahawu (JTM1 dan JTM2) dan juga dari Gunung Soputan (JTS1 dan JTS2), akan tetapi terdapat perbedaan satu basa nukleotida antara sampel dari Gunung Mahawu dan Gunung Soputan. Pada basa nukleotida ke 697, sampel Nepenthes sp. dari Gunung Mahawu memiliki basa $G$ (Guanin) sedangkan sampel dari Gunung Soputan memiliki basa $T$ (Timin) seperti yang terlihat pada Gambar 2. Perbedaan tersebut terjadi karena adanya transversi basa antara $G \leftrightarrow T$. Transversi jarang ditemukan dan frekuensinya lebih rendah dibandingkan transisi. Transisi cenderung menghasilkan lebih sedikit subtitusi asam amino sehingga cenderung lebih stabil didalam populasi dan dianggap 
sebagai fenomena polimorfime nukleotida tunggal (Single nucleotide polymorphism) (Tallei et al 2016).

Hasil penelitian menunjukkan kemiripan 99\% untuk Nepenthes sp. dari Gunung Mahawu (JTM) dan $100 \%$ untuk Nepenthes sp. dari Gunung Soputan (JTS) dengan spesies N. fusca AF315936 dan N. pilosa AF315919, sedangkan spesies $N$. faizaliana hanya berbeda satu nukleotida dengan keempat sampel (JTM1, JTM2, JTS1, dan JTS2) pada posisi 677 . N. clipeata memiliki dua nukleotida yang berbeda dengan keempat sampel yaitu pada posisi 198 dan 744, Spesies kerabat terjauh dengan keempat sampel adalah $N$. danseri di mana perbedaan yaitu 7 nukleotida pada posisi 185, 416, 602, 607, 608, 663,702 , serta spesies $N$. sibuyanensis dan $N$. bellii masingmasing berbeda 6 nukleotida pada posisi 185, 416, 602, 607, 608, 702 (Gambar 3).

Pohon filogenetik dibuat dengan menggunakan model UPGMA yang mengasumsikan bahwa laju evolusi adalah konstan di sepanjang sejarah evolusi dari taksa yang diuji dan menggunakan jarak genetik Kimura 2-parameter (Kimura, 1980). Gambar 4, menunjukkan posisi JTM dan JTS di dalam pohon filogenetik. Sampel JTS terletak di dalam satu klaster dengan N. pilosa, $N$. fusca dan $N$. maxima. Meski tingkat kemiripan sampel JTS dengan $N$. maxima 99,75 \%, mereka berada dalam satu klaster dengan $N$. fusca dan $N$. pilosa yang tingkat kemiripannya $100 \%$ dengan JTS. Perbedaan nukleotida antara JTS dengan $N$. maxima hanya disebabkan oleh adanya ketidakterbacaan nukleotida pada posisi 719 dan 741 (ditandai dengan $\mathrm{N})$.

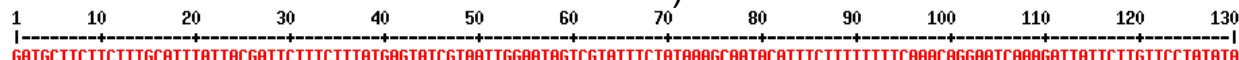

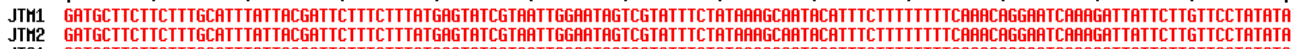

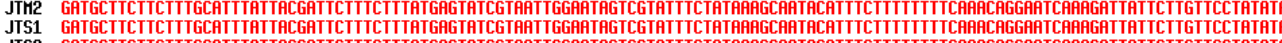

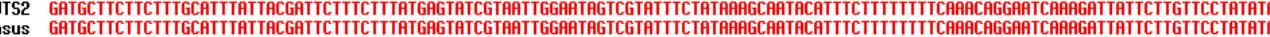

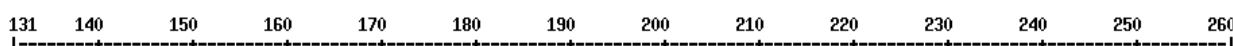

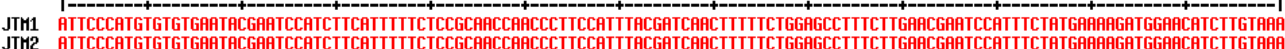

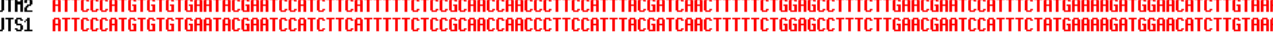

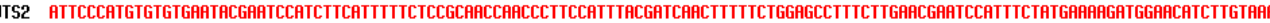

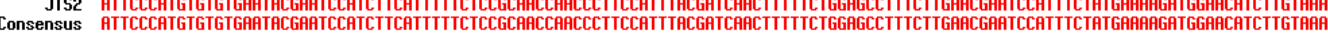

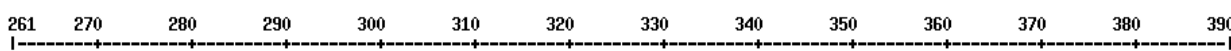

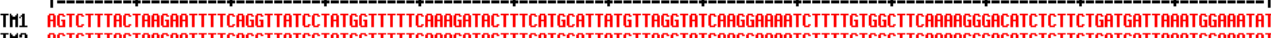

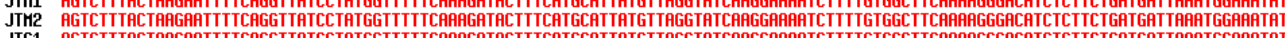

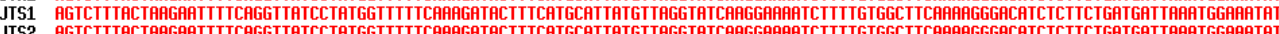

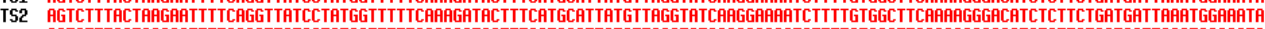

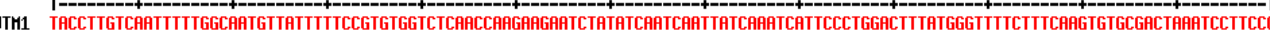

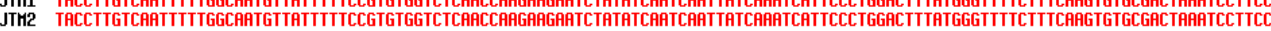
JACCTTGזChн TACCTTGC

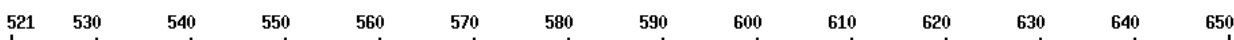

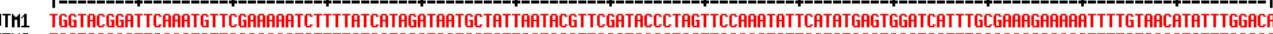

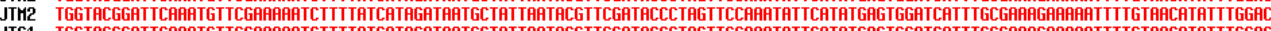

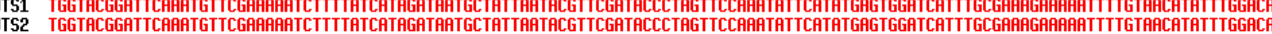

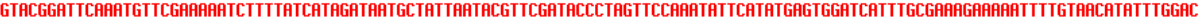

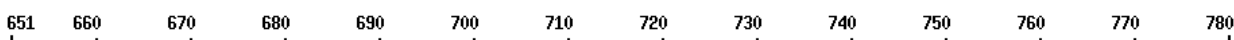

JTM1 TCC.

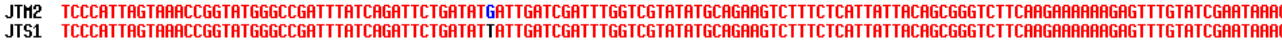
JTS2

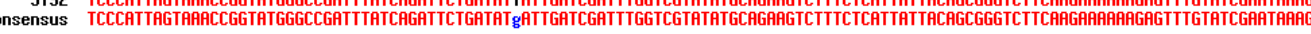
$\begin{array}{llll}781 & 790 & 800 & 810814\end{array}$

JTM1 TATATACTTCGACTTTCTTGTGCTAGARCTTTGG

JTS1 TATRTACTTCGACTTTCTTGTGCTAGคACTITGG

JTS2 TATATACTTCGACTTCTCTIGTCCTAGARCTTTGG

Consensus TATATACTTCGACTTCTTGTGCTAGRACTTTGG
}

Gambar 2. Penjajaran urutan sekuens JTM1, JTM2, JTS1 dan JTS2 menggunakan software Multalin 
Dengan demikian diduga $N$. maxima memiliki tingkat kemiripan 100\% dengan JTM, JTS, N. pilosa, dan N. fusca.

Metode Kimura-2-parameter digunakan dalam menentukan jarak genetik dalam penelitian ini karena dapat menunjukan subtitusi basa per situs antar sekuens sampel
Nepenthes sp. Jarak genetik di antara klaster JTS yaitu 0,000, sedangkan jarak antara klaster JTS dengan JTM yaitu 0,001. Hasil tersebut menandakan bahwa kemungkinan besar kedua tumbuhan tersebut merupakan spesies yang sama atau merupakan subspesies.

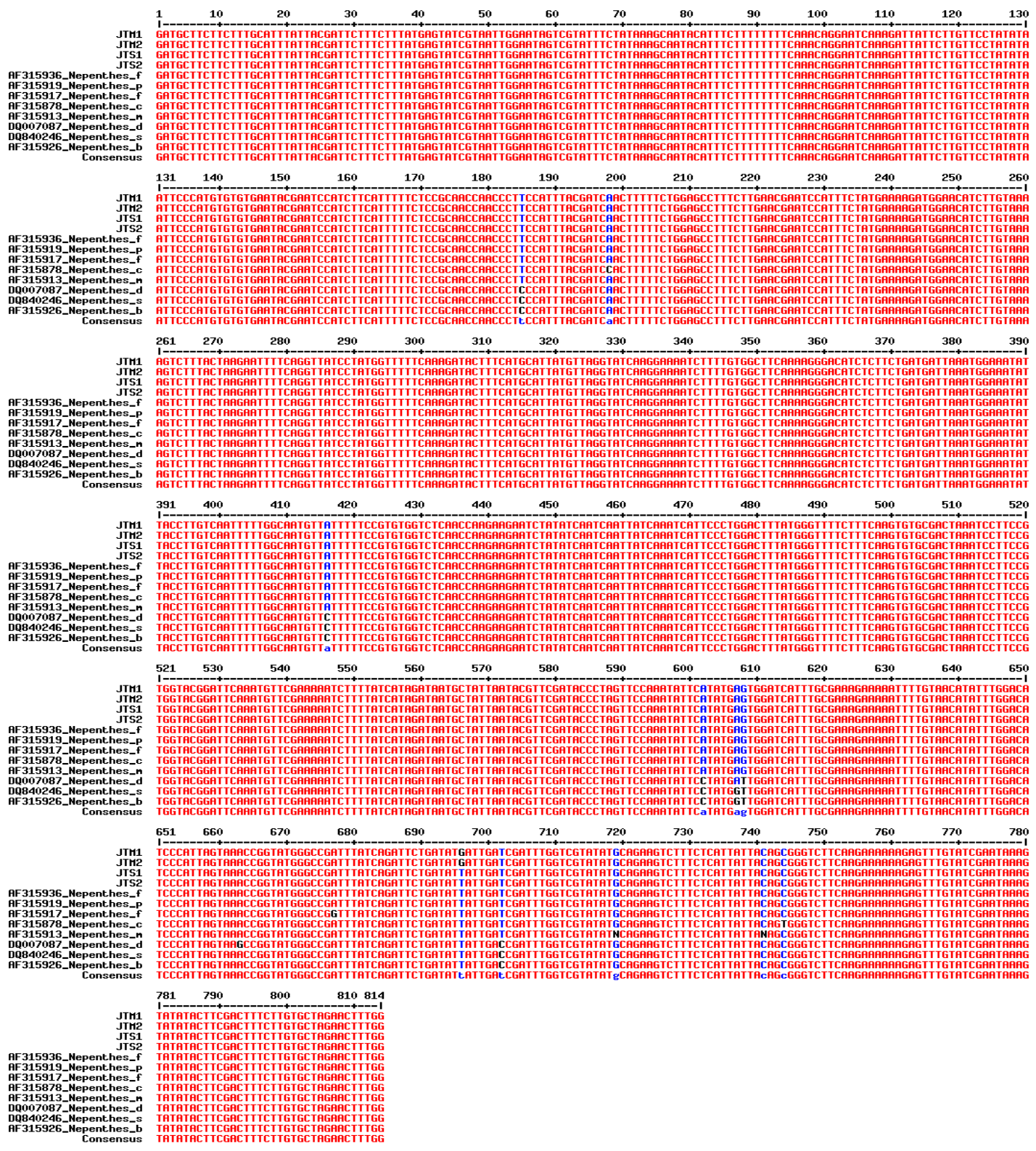

Gambar 3. Penjajaran sekuens gen matk Nepenthes sp. dari Gunung Mahawu dan Soputan dengan kerabat terdekat dari jenis Nepenthes di GenBank dan BOLD Systems 


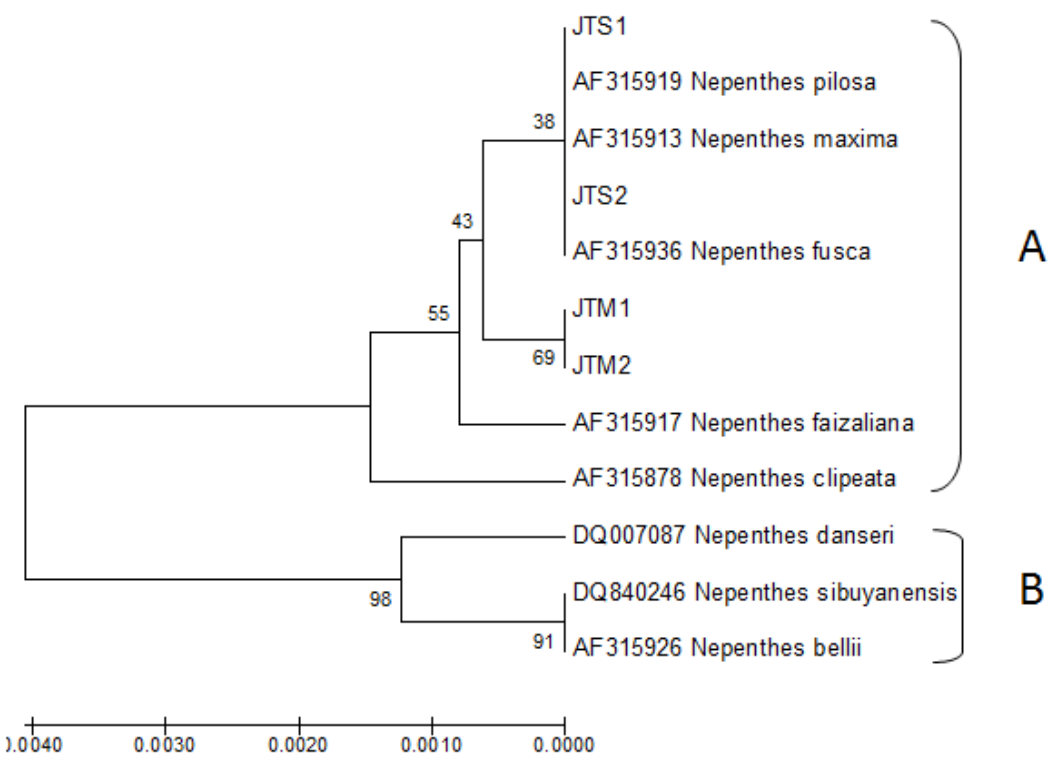

Gambar 4. Pohon filogenetik diperoleh menggunakan metode UPGMA (Sneath dan Sokal, 1973). Jarak evolusi dihitung menggunakan metode Kimura 2parameter (Kimura 1980). Analisis evolusi dilakukan dalam MEGA7 (Kumar et al. 2016)

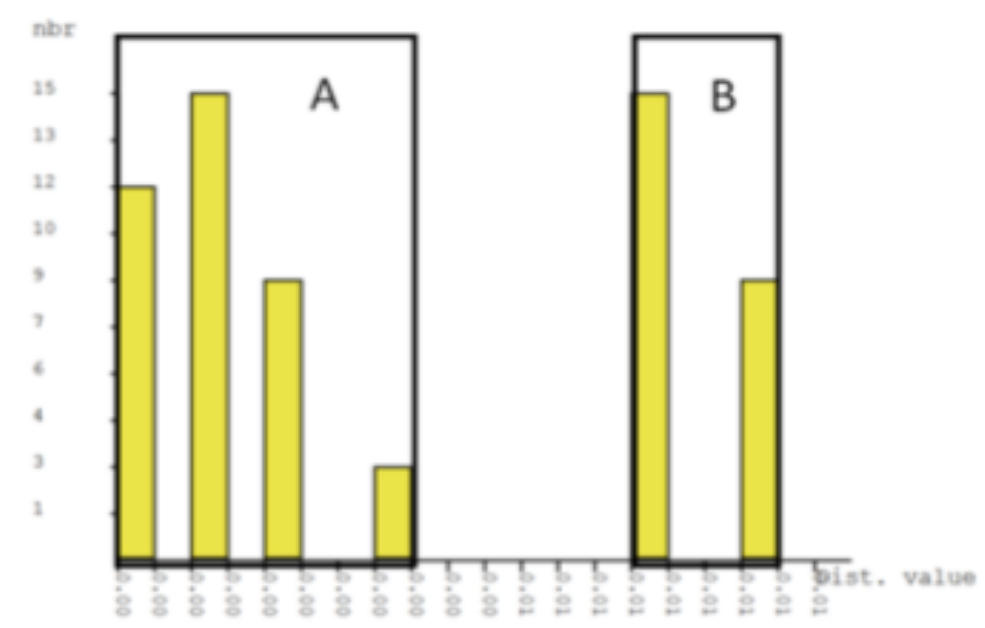

Gambar 5. Analisis menggunakan ABGD (Automatic Barcode Gap Discovery) untuk membatasi spesies-spesies Nepenthes sp. yang digunakan dalam penelitian ini

Menurut Tallei et al. (2016), tumbuhan Astragalus (Fabaceae), di hubungan kekerabatan akan semakin dekat jika memiliki nilai jarak genetik yang kecil. Nilai jarak genetik interspesies di antara genus Nepenthes sp. berkisar antara 0,0000,010 . Jarak genetik tersebut cukup besar bila dibandingkan dengan hasil jarak genetik matk kelompok mana rata-rata minimal jarak genetik interspesies (interspecific distance) untuk setiap spesies yaitu 0,0071 \pm 0,0064 , sedangkan jarak intraspesies (intraspecific distance) yaitu 0,0014 \pm 0,0022 (Zheng et al., 2014). rata-rata jarak genetik interspesies $0,042 \pm 0,0030$ dan intraspesies 0,005 
untuk tumbuhan famili Myristicaceae (Newmaster et al. 2008), serta jarak genetik rata-rata interspesies $0.0093 \pm 0.0081$ dan intraspesies $0,0016 \pm 0,0016$ untuk tumbuhan Rosaceae (Pang et al. 2010). Apabila merujuk kepada penelitian-penelitian tersebut dan berasumsi bahwa ambang batas jarak intraspesies berkisar antara 0 sampai 0,0026, maka tumbuhan JTM, JTS, N. fusca, $N$. pilosa, $N$. maxima, dan $N$. faizaliana merupakan spesies yang berkerabat dekat. Hal ini ditunjang dengan pohon filogenetik yang menempatkan tumbuhan-tumbuhan tersebut dalam posisi yang berdekatan.

Untuk delimitasi spesies digunakan ABGD (Automatic Barcode Gap Discovery) yang merupakan perhitungan komputer yang secara efisien digunakan untuk membedakan intraspesies sehingga dapat digunakan untuk membatasi spesies dalam kelompok organisme uji (Puillandre et al. 2011). Hasil penelitian menunjukkan bahwa Nepenthes sp. terbagi menjadi 2 kelompok besar (A dan B) seperti yang terlihat pada Gambar 4 dan 5 . Kelompok A terdiri atas 4 kelompok yaitu kelompok I merupakan JTS1, JTS2, Nepenthes fusca AF315936, Nepenthes pilosa AF315919. Kelompok II terdiri atas JTM1 dan JTM2. Kelompok III terdiri atas Nepenthes faizaliana AF315917. Kelompok IV terdiri atas Nepenthes clipeata AF315878S. Kelompok B terdiri atas 2 kelompok, yaitu Kelompok I merupakan Nepenthes danseri DQ007087. Kelompok II terdiri atas Nepenthes sibuyanensis DQ840246 dan Nepenthes bellii AF315926. Apabila dilihat dari Gambar 5, terdapat barcode gap di antara Kelompok I dengan Kelompok II. Apabila mempertimbangkan barcode gap tersebut sebagai pembatas spesies, maka diasumsikan bahwa JTM, JTS, $N$. fusca, $N$. pilosa, N. maxima, $N$. faizaliana, dan N. clipeata merupakan spesies yang sama. sehingga variasi intraspesies untuk Nepenthes berada dalam rentang $0,000-0,004$.

\section{KESIMPULAN}

Perbandingan sekuens gen matk menunjukan adanya varisi sekuens dengan perbedaan satu basa nukleotida antara sampel Nepenthes sp. dari Gunung Mahawu (JTM1 dan JTM2) dan Gunung Soputan (JTS1 dan JTS2). Perbandingan sekuens sampel Nepenthes sp. dari Gunung Mahawu dan Gunung Soputan dengan kerabat terdekatnya di GenBank dan Bold system menunjukan perbedaan 1-7 basa nukleotida. Nilai jarak genetik interspesies Nepenthes sp. yaitu berkisar antara 0.000 sampai 0.010 . Hasil analisis menggunakan ABDG mengasumsikan bahwa JTM, JTS, N. fusca, N. pilosa, N. maxima, $N$. faizaliana, dan $N$. clipeata merupakan spesies yang sama, karena variasi intraspesies untuk Nepenthes berada dalam rentang $0,000-0,004$.

\section{DAFTAR PUSTAKA}

Butarbutar RR, Purnomo M, Hakim L, Sastrahidayati IR, Soemarno (2014) Strategic development of nature tourism based on plant species at the Mahawu mountainous region, North Sulawesi, Indonesia. Journal of Biodiversity and Environmental Sciences 5 (5):241-252

Kimura M (1980) A Simple method for estimating evolutionary rate of base substitutions through comparative studies of nucleotide sequences. Journal Molecular Evolution 16:111-120

Kolondam BJ, Lengkong $E$, PoliiMandang J, Pinaria A, Runtunuwu S (2013) Barcode DNA Anthurium gelombang cinta (Anthurium plowmanii) 
berdasarkan gen $r b c L$ dan matK. Jurnal Bios Logos 3 (1):17-25

Kress WJ, Erickson DL (2008) DNA barcodes: Genes, genomics and bioinformatics. Departement of Botany. Proceedings of The National Academy of Sciences USA 105:2761-2762

Kress WJ, Erickson DL, Swenson NG, Thompson J, Uriarte $M$, Zimmer JK (2010) Advances in the use of DNA barcodes to build a community phylogeny for tropical trees in a Puerto Rican forest dynamics plot. Plos One 5 (11):e15409

Kumar S, Stecher G, Tamura K (2016) MEGA7: Molecular evolutionary genetics analysis version 7.0 for bigger datasets. Molecular Biology and Evolution 33:1870-1874

Mansur M (2008) Penelitian ekologi Nepenthes di laboratorium alam hutan gambut Sabangau kereng bangkirai Kalimantan Tengah. Jurnal Teknologi Lingkungan 9: 67-73

Mithofer A (2011) Carnivorous pitcher plants: Insights in an old topic. Phytochem 72 (13): 1678-1682

Newmaster SG, Fazekas AJ, Steeves AD, Janovec J (2008) Testing candidate plant barcodes regions in the Myristicaceae. Molecular Ecology Resources 8(3): 480-490

Pang X, Song J, Zhu Y, Xu H, Huang L, Chen S (2010) Applying plant DNA barcodes for Rosaceae species identification. Cladistics 27(2):165-170

Pavlovic A, Slováková L, Šantrùèek J (2011) Nutritional benefit from leaf litter utilization in the pitcher plant Nepenthes ampullaria. Plant Cell Environment 34:18651873

Puillandre N, Lambert A, Brouillet S, Achaz G (2011) ABGD, Automatic Barcode Gap Discovery for primary species.
Molecular Ecology 21 (8):18641877

Samsurianto (2010) Induksi tunas mikro kantong semar (Nepenthes sp.) in vitro. Bioprospek 7 (2):6776

Scholz I, Buckins M, Dolge L (2010) Slippery surfaces of pitcher plants: Nepenthes crystals minimize insect attachment via microscopic surface. Journal of Experimental Biology 213:11151125

Shingh B, Phukan S, Singh VN, Borthakur SK (2011) Conservation strategies for Nepenthes khasiana in Nokrek biosphere reserve of Garo hills, Northeast, India. International Journal of Conversation Science 2(1):55-64

Sneath PHA, Sokal RR (1973) Numerical taxonomy. Freeman, San Francisco

Tamura K, Stecher G, Peterson D, Filipski A, Kumar S (2013) MEGA6, Molecular Evolutionary Genetics Analysis version 6.0. Molecular Biology and Evolution 30:2725-2729

Tallei TE, Kolondam BJ (2015) DNA barcoding of Sangihe Nutmeg (Myristica fragrans) using matk gene. HAYATI Journal of Biosciences 22(1):41-47

Tallei TE, Rembet RE, Pelealu JJ, Kolondam BJ (2016) Sequence variation and phylogenetic analysis of Sansevieria trifasciata (Asparagaceae). Bioscience Research 13(1):01-07

Zhang X, Xuan G, Guo Z, Li L, Song X, Liu S, Zang Y, Li Y, Lin C, Wei $S$ (2014) Genetic diversity and population structure of Rheum tanguticum (Dahuang) in China. Chinese Medicine 9:26 